\title{
Claystone as a Potential Host Rock for Nuclear Waste Storage
}

\author{
Károly Lázár and Zoltán Máthé
}

Additional information is available at the end of the chapter

http://dx.doi.org/10.5772/48123

\section{Introduction}

Nuclear energy is widely used for production of electricity. There are several advantages of this type of generation of electric power, but severe drawbacks also emerge. These difficulties should be eliminated for appropriate large-scale utilization. One of these difficulties is the formation of long life-time isotopes during the nuclear reactions (fission and capture of neutrons). The life-time of some of these products reaches even the $10^{5}-10^{6}$ year range. There are procedures, by which these long life time isotopes can be extracted or eliminated (reprocessing and transmutation), but finally, some isotopes are still remaining with significantly decreased activity with life-times in ca. thousand years range.

The reliable and safe deposition of these products should be elaborated. The long-term geological disposal is considered as a suitable option for the isolation of these isotopes from the biosphere during their long life-time. Properties of various types of host rocks were evaluated from this aspect, crystalline (granitic), clayey or even salt types among them.

The clayey host rocks exhibit some andvantages in this respect, namely they may have significant capacity for sorption and ion exhange, both processes considerably may retard the migration of dangerous components. Some of these formations have been characterised in very details - even underground laboratories were established in them for their in situ characterisation (Callovo-Oxfordian formation in France, Opalinus Clay in Switzerland, and Boom Clay in Belgium).

The issue is about to be also addressed in Hungary. C.a. $40 \%$ of electricity is procuded in a nuclear power plant since the 1980's. A significant amount of collected spent fuel has been stored in temporary repositories since then. The procedure for final deposition should be elaborated and implemented within the next $20-30$ years. 
A preliminary screening had been performed, the Boda Claystone Formation has emerged as a potential media for deposition. This formation is an extensive one - samples collected from different parts of it have been characterised. An underground research facility had even been established in it in a depth of $1050 \mathrm{~m}$ from 1994 - 1999. A detailed characterization of the formation has been performed based on the data collected from results of measurements performed in this facility.

The intention with the recent chapter is to provide an illustration and to present some aspects of the evaluation on the potential possibilities of the application of clayey geological media for storage of wastes of nuclear origin. Following this short introduction in the second part an overview is given on the types and most important long life-time isotopes, and on the ongoing processes which might occur during the several thousand years of operation time of the waste storage facility. In the third part a short account is presented on the properties of clay minerals which influence their behaviour as an isolation media. Results of some specific evaluations of clays (Callovo-Oxfordian, Opalinus) are also presented in this part to provide an overview and comparison. In the fourth part a more detailed description and characterisation of Boda Claystone is presented. Its formation, components, characterisation of clay minerals is described in more detail. Special attention is devoted to measurements correlated to isolation properties of this media against migration of long life-time isotopes.

\section{Nuclear wastes}

The production of nuclear wastes is connected primarily to generation of electricity in nuclear power plants. Other sources of nuclear wastes are common as well. For example those radionuclides which had been used for therapeutical or industrial applications. These latter radioisotopes can be generated by neutron or proton irradiation of certain stable isotopes, they usually have short half life-times (less than ca. 30 year), and their amount is comparatively small. The nuclear wastes usally are classified to two main groups: to lowlevel and to high-level wastes. The criteria for the distinction are the half-life and the amounts of the radionuclides present in them. The main components in the low-level wastes have short half life-times, they can be stored in ground surface facilities, their operation time is expected to elapse for a few hundred years. In contrast, the radioisotopes in the high level nuclear wastes have considerably longer half life-time (up to the range of $10^{5}-10^{6}$ year). Construction of underground facilities is considered for the final disposal as a reliable mean to maintain an appropriate isolation from the biosphere for the long time interval necessary for the decay of the critical isotopes [1]. One option for the disposal of high level wastes can be the utilisation of clays as isolating media. Prior to discussing some properties of clays it is worth to discuss some properties of the high level wastes in more details with particular respect to their possible interactions with clayey minerals occuring during the long operation time of the disposal facility.

\subsection{High level nuclear waste}

In conventional nuclear reactors the energy is produced by splitting ${ }^{235} \mathrm{U}$ nuclei with neutron irradiation. In a conventional fuel type the ${ }^{235} \mathrm{U}$ content is enriched to ca. $4 \%$ from the 
natural $0.6-0.8$ per cent in the ores. The rest of the fuel is ${ }^{238} \mathrm{U}$ (both isotopes in oxide form). The fission of the heavy $U$ nucleus results in formation of two novel nuclei, and a few neutrons are also emitted which may propagate the process. A small difference exists between the masses of the starting and final products. The corresponding energy equivalent of this difference is the generated heat in the final gross balance. A variety of nuclei are produced in the fission, a number of them is instable and will be stabilized in later processes by emitting $\beta$ or $\gamma$ radiation. There are several instable nuclei among these fission products which have considerably long half life-time (Table 1.) Further on, in the nuclear reactors not only fission but capture of neutrons may also proceed. For instance ${ }^{238} \mathrm{U}$ may capture one neutron and the with simultaneous $\beta$ radiation ${ }^{239} \mathrm{~Np}$ forms. This nucleus is also instable and emits one electron by forming ${ }^{239} \mathrm{Pu}$. This pruduct is still instable but is has a much longer life-time. Plutonium can also be used as a reactor fuel, but for splitting of ${ }^{239} \mathrm{Pu}$ nuclei other type of reactor conditions are optimal [2].

\begin{tabular}{|c|c|c|c|}
\hline Isotope & $\begin{array}{c}\text { Half-time } \\
10^{6} \text { year }\end{array}$ & Rel \% & $\begin{array}{c}\beta \text { energy } \\
\text { keV }\end{array}$ \\
\hline${ }^{99} \mathrm{Tc}$ & 0.211 & 6.1 & 292 \\
${ }^{93} \mathrm{Zr}$ & 1.53 & 5.4 & 90 \\
${ }^{135} \mathrm{Cs}$ & 2.3 & 6.9 & 210 \\
${ }^{129} \mathrm{I}$ & 15.7 & 0.8 & 198 \\
\hline
\end{tabular}

(Remark: the relative abundance depends on the extent of the burnout of the fuel)

Table 1. Some typical long life-time fission isotopes produced in nuclear reactors

A large variety of other short half life-time isotopes are also formed, they influence the working conditions of the reactor. After a certain period of the usage (3-4 years) the fuel rods are removed from the reactor. They can be stored afterwards without any further utilization. They are highly radiating, a great amount of heat is still generated in them (without exposed them to neutron irradiation). Thus, after operation they are usually kept in a water pool, then in other temporary storage facilities. But, as was shown above, isotopes with long half life-time are present in them, their final safe disposal should be provided in some manner. This type of the straight utilization of the nuclear fuel is called open fuel cycle.

Another option is the reprocessing. The used fuel still contains ${ }^{235} \mathrm{U}$ amounting to ca. 1\%, and it is also worth to extract the newly formed transuranic isotopes (eg. ${ }^{239} \mathrm{Pu}$ ) which can be utilized as a nuclear fuel (although in modified type of reactors). During the various steps of the reprocession the amounts of the long life-time isotopes are significantly decreased, but they are still present in significant amounts at the end of the procedure (Figure 1). This version of utilization is named closed fuel cycle. It is seen that the activity is rather high, even after c.a. one million years of storage the tera-Becquerel level is still maintained.

The transmutation is also a further possibility to reduce the amounts of the radiounuclides present in the high level waste. Specific controlled nuclear reactions can be initiated by irradiating different target isotopes with accelerated electrons, protons, etc. and the energy of stabilisation from the ustable target nuclei can also be extracted. This process is very 


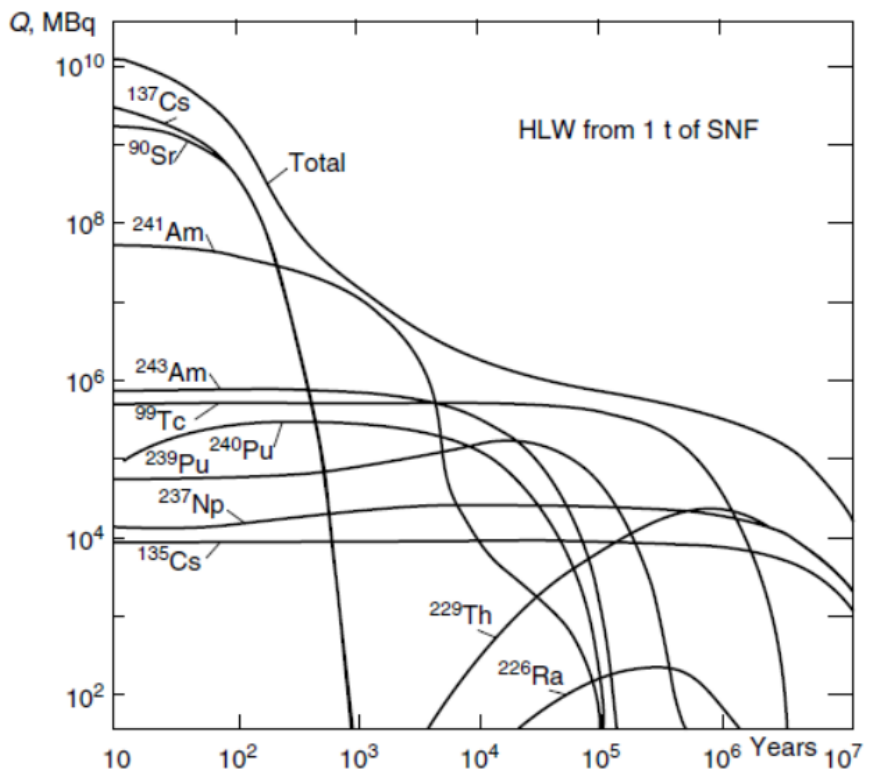

Figure 1. Activity of high level waste remaining after processing of 1 ton spent fuel in dependence of time (reprinted with permission from [1].)

sophisticated, should be performed in different manner with each isotopes separately, thus its practical application cannot be expected in the near future.

This brief overview can be summarised with the conclusions that long life-time isotopes are byproducts in generation of electricity in nuclear power plants. The life time of some of these isotopes may expand to even $10^{6}$ years. The amounts of this isotopes can be decreased by various procedures but they cannot be fully eliminated.

Due to their long life-time these waste isotopes should be isolated from the biosphere. By commonly accepted recent considerations a perspective solution might be the disposal in geological media, i.e. host rocks.

\subsection{Disposal and subsequent possible processes in host rocks}

Two types of barriers are usually mentioned with respect to the geological disposal, the engineered and the natural ones. The engineered barrier comprises the immediate capsulation (metal cannister), the backfill material (high sorption capacity porous material e.g. bentonite, etc.) and the strengthened wall of the shaft (made of concrete) in which the cannisters are situated. The natural barrier is the geological media. In the first few hundred years the engineered barrier should sustain the isolation from the long half-life isotopes. During this period the components of this barrier will probably lose their ability for protection due corrosion and other hydrothermal processes, Thus the role of the natural barrier will probably gain emphasised importance later on [3]. 
Several processes may take place in the working cycle of a disposal site. It should be taken into account that the extent of decaying nuclei is large, thus, a significant amount of heat is generated simultaneously. Further on, most of the design schemes consider deposition sites below the ground level, thus presence some amount of water cannot be excluded either. In addition, due to radiation effects, free oxidizing or reducing radicals may also form, (e.g. $\cdot \mathrm{OH}$ from water).

The situation can be illustrated for example with the case of neptunium on a Pourbaix (Eh$\mathrm{pH}$ ) diagram [4]. At the closure of the disposal site the environment is exposed to air, the $\mathrm{pH}$ of the ground water (in equilibrium with the $\mathrm{CO}_{2}$ of the air) is c.a. 5.5 (position A in Figure 2.). After the closure the site is isolated, the $\mathrm{pH}$ approaches to the mean of the rock (usually it is between 7 and 8). As the time elapses, the concrete sealing around the engineered barrier starts to erode, the $\mathrm{pH}$ in the close environment may increase to $\sim 10$. Later, very slowly the system may approach the state charcterising generally the whole isolating rock host (Eh -0.1 V, pH 7.5 can be estimated, see Figure 2).

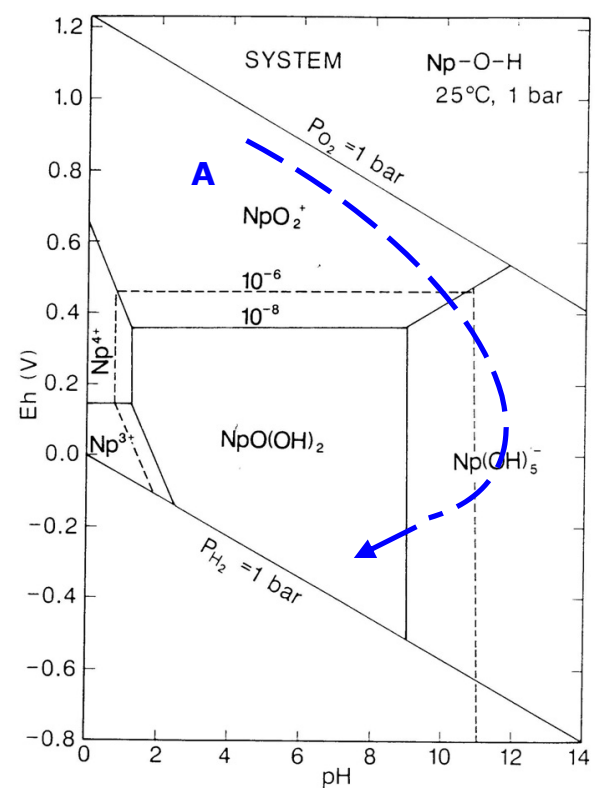

Figure 2. Schematic representation of the change of conditions on the Eh-pH diagram of Np during the life-time of a disposal site. Processes start with the construction, from a stage marked with A. (the base Eh-pH diagram is taken from [4])

It is seen in Figure 2 that $\mathrm{Np}$ is present as a cationic species in $\mathrm{NpO}_{2}{ }^{+}$form at the start, which can be sorbed in aqueous media on the components of the rock minerals. However, the speciation changes with the increase of $\mathrm{pH}$, the anionic $\mathrm{Np}(\mathrm{OH}) 5^{-}$component will be dominant later. This component probably will migrate easily due to its negative charge. Having migrated for several hundred years $\mathrm{NpO}(\mathrm{OH})_{2}$ component may be formed at the end, which is neutral, thus it will precipitate. 
The simplified example may already provide an impression that the speciation and the $\mathrm{pH}$ dependence may be different for the various long half life-time isotopes. The real situation is far more sophisticated: the temperature may reach $80-100{ }^{\circ} \mathrm{C}$ (depending on the time elapsed, and the depth), the hydrostatic pressure may be in the $50-80$ bar range (depending on the depth), various interlinked geochemical processes may occur under these conditions which influence the spreading of isotopes in the host rock (for further details see e.g. in [5]).

\subsection{Simple practical approaches to estimate the speed of migration}

The speed of migration of the various long half life-time components is a crucial factor for the evaluation of the properties of the perspective host rocks. In the first approach the migration of isotopes can be considered as a cyclic repetition of frequent sorption/desorption steps in a slowly flowing aqueous media. The strength of sorption can simply be characterised by the distribution coefficient, $K_{d}$.

$$
K_{d}=\frac{I_{0}-I_{e}}{I_{e}} \cdot \frac{V}{m}
$$

where $I$-s are concentration (activity) values of the studied isotope, $I_{0}$ in the starting solution, $I_{e}$ in equilibrium, after having kept the $m$ mass of sample in contact with $V$ volume of solution.

The $K_{d}$ values of various rock samples can easily be obtained, the concentration change of the particular ion should only be determined experimentally. Consequently, $K_{d}$ values are widely used. Further on, the speed of the migration relative to the slowly flowing media can also be estimated by using the $K_{d}$ values:

$$
\frac{v_{\text {rad }}}{v_{g w}}=\frac{1}{1+\left(\frac{1-\varepsilon}{\varepsilon}\right) \cdot \rho \cdot K_{d}},
$$

where $v_{\text {rad }}$ is the velocity of migration of the given radionuclide, $v_{g} w$ is the velocity of the flow of the ground water, $\varepsilon$ is the porosity, $\rho$ is the density and $K_{d}$ is the distribution coefficient of the isotope in question.

Equation (2) has been widely used since $K_{d}$ values can easily be measured. However it should be used with particular precaution. Namely, it should be taken into account that:

- The structure of the powdered rock is different from the real one - usually not all the mineral components are contacted with the aqueous medium in the real case.

- The mass ratios of the liquid solution related to the amount of the solid rock are distinctly different in the $\mathrm{K}_{\mathrm{d}}$ determinations and in the real situation. In the former instance the liquid component is applied in large excess (at least ten-fold), whereas the conditions in the reality are the opposite, usually only a few per cent of pore water is present in the rocks. 
- Equation (2) provides a relative, retention velocity. It may occur that the flow is practically zero in the rocky media, whilst the simultaneous diffusion takes place still. Under these conditions Eq. (2) cannot be applied at all.

There are other simple experimental methods by which more reliable determination of the crucial constants can be provided. Rock samples preserved in conditions closer to the natural ones are suitable for this type of studies, obtained for example from bore cores. One simple type of these more reliable measurements is the so-called "break-through" type. Two compartments are separated with the studied borecore sample in the measuring cell. One compartment contains the very dilute solution of the studied tracer isotope (in ground water), and the break-through (i.e. the appearance) and the rate of further increase of its concentration is followed in the ground water in the other, opposite compartment. If the trace isotopes are used in really low concentrations the experimental conditions may actually be close to the real, natural ones. In other words the applied small concentration gradient hardly modifies the natural conditions. On the other side, however, rather long time intervals are necessary to perform these studies (several hundred days). From these measurements the effective diffusion constant $\left(D_{\text {eff }}\right)$ can directly be determined (Eq. 3 )

$$
\frac{C^{\prime}(t)}{C_{0}}=\frac{A D_{e f f}}{V^{\prime} L} t-\frac{\alpha A L}{6 V^{\prime}}
$$

where $C_{0}$ is the original concentration (activity) of the isotope in a compartment at the start of the experiment, $C^{\prime}(t)$ is the concentration measured in the opposite compartment, after having the break-through started, $A$ is the cross section of the borecore sample, $L$ is the thickness of the borecore, $V^{\prime}$ is the volume of the compartment. $\alpha$ is the so called retention factor, its value is related to the delay of the break-through. $D_{\text {eff }}$ is proportional to the slope of the increase of concentration of the studied isotope with time in the originally non-active compartment.

$D_{\text {eff }}$ is one of the most appropriate parameters which can be used for the characterisation of rocks from the point of view of migration of isotopes expected to proceed in them.

\section{Application of clayrocks for the disposal}

Clay rocks are widely considered as appropriate media for final waste disposal site. Clay minerals have several advantageous properties for the isolation. They have open, layered structure in which they easily ad- or chemisorb cations.

\subsection{Recent investigations on clayrocks}

Due to the advantageous properties of clayrocks significant amount of efforts is devoted to investigate them as optional disposal sites. For instance, at the Nuclear Energy Agency (NEA) a working group has been formed devoted to study the scientific bases for stability and buffering capacity of deep geological waste management systems („Clay Club”). This Club organised several conferences, and the results have been published in workshop proceedings [6]. Other specific conferences have also been devoted to this topic (see e.g. [7]). 
At present, three clayrock types have been characterised in very detail in Europe. Namely, the Callovo-Oxfordian formation in Bure, France, the Opalinus Clay in Mont Terri, Switzerland, and the Boom Clay in Mol, Belgium [8]. Some basic properties and some characteristic minerals of these clays are summarized and compared in Table 2 [9]. Properties of Boda Claystone are also included for later comparisons.

\begin{tabular}{|c|c|c|c|c|c|c|c|c|}
\hline \multirow[t]{2}{*}{ Clayrock } & Age & Depth & $\begin{array}{l}\text { Max. } \\
\text { temp. }\end{array}$ & $\begin{array}{c}\text { Pore } \\
\text { water }\end{array}$ & $\begin{array}{c}\text { Organic } \\
\text { matter }\end{array}$ & $\begin{array}{c}\text { Clay } \\
\text { fraction }\end{array}$ & Albite & Calcite \\
\hline & $10^{6}$ year & $\mathrm{m}$ & ${ }^{\circ} \mathrm{C}$ & $\%$ & $\%$ & $\%$ & $\%$ & $\%$ \\
\hline Boom & $30-36$ & 200 & 16 & $\sim 25$ & $2-3$ & $35-65$ & $1-2$ & $\sim \sim 1$ \\
\hline $\begin{array}{l}\text { Callovo- } \\
\text { Oxfordian }\end{array}$ & 155 & 500 & 40 & $\sim 7$ & $\sim 1$ & $\sim 40$ & $\sim 1$ & $\sim 35$ \\
\hline Opalinus & 180 & 500 & 85 & $\sim 7$ & $\sim 1.5$ & $45-60$ & $\sim 1$ & $4-8$ \\
\hline Boda & 250 & 1000 & 220 & $\sim 2$ & - & $35-50$ & $4-8$ & $3-5$ \\
\hline
\end{tabular}

Table 2. Certain characteristic data of clayrock types considered as perspective host [9].

Principally, each rock types contain clays in large proportions. Hovewer, in other properties the clays exhibit significant differences. Their ages, the maximal temperatures experienced during formation, water contents, characteristic minerals present in them etc. are distinctly different, attesting their unique history of formation for each of them.

The safety aspects for the construction of disposal sites have also been discussed and evaluated in detail (see eg. for the Callovo-Oxfordian in [10], for the Oplalinus Clay in [11]).

\section{Boda Claystone}

There had been considerations with respect to the future disposal sites for high level nuclear wastes in Hungary, too. Boda Claystone emerged as potential host. A brief comparison of data shown in the previous Table 2 shows that each clayrock has distincly different properties - each of them should be characterized specifically. Thus, Boda Claystone was characterised in the course of various programmes as well. Some results of these characterisations are summarized below.

\subsection{General characterisation}

The Upper Permian sedimentary sequence of the Boda Claystone Formation (BCF) is located in Western Mecsek Mountains, southern Transdanubia, SW Hungary. The Mecsek Mts. is part of the Tisza Megaunit comprising the basement of the south-eastern half of the Pannonian Basin [12] (Figure 3). The geological map of BCF is shown in Figure 4.

Following the Variscan orthogeny the continental sedimentation in the Mecsek Mts. began in the Early Permian and lasted until the Lower Triassic. The BCF is part of this about 2000$4000 \mathrm{~m}$ thick siliciclastic sequence (continental red beds); its transition with underlying 
Cserdi Formation is conformable, while the boundary with overlying strata of the Kővágószőlős Formation is usually sharp (Figure 5) [13].

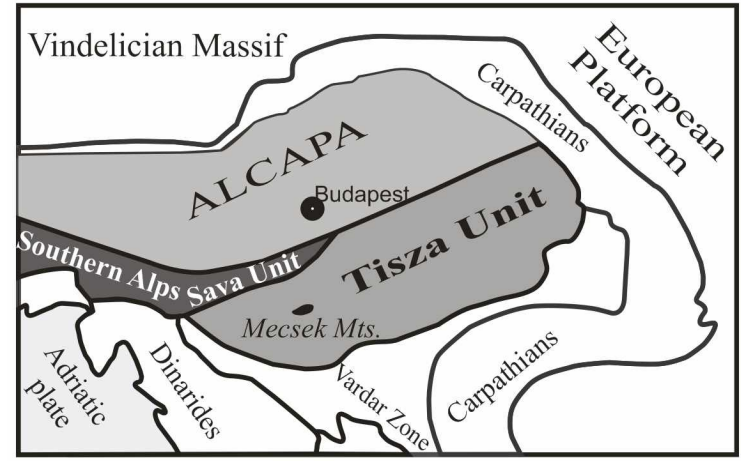

Figure 3. Overview of plate tectonic units in the Pannonian Basin (after [12]).

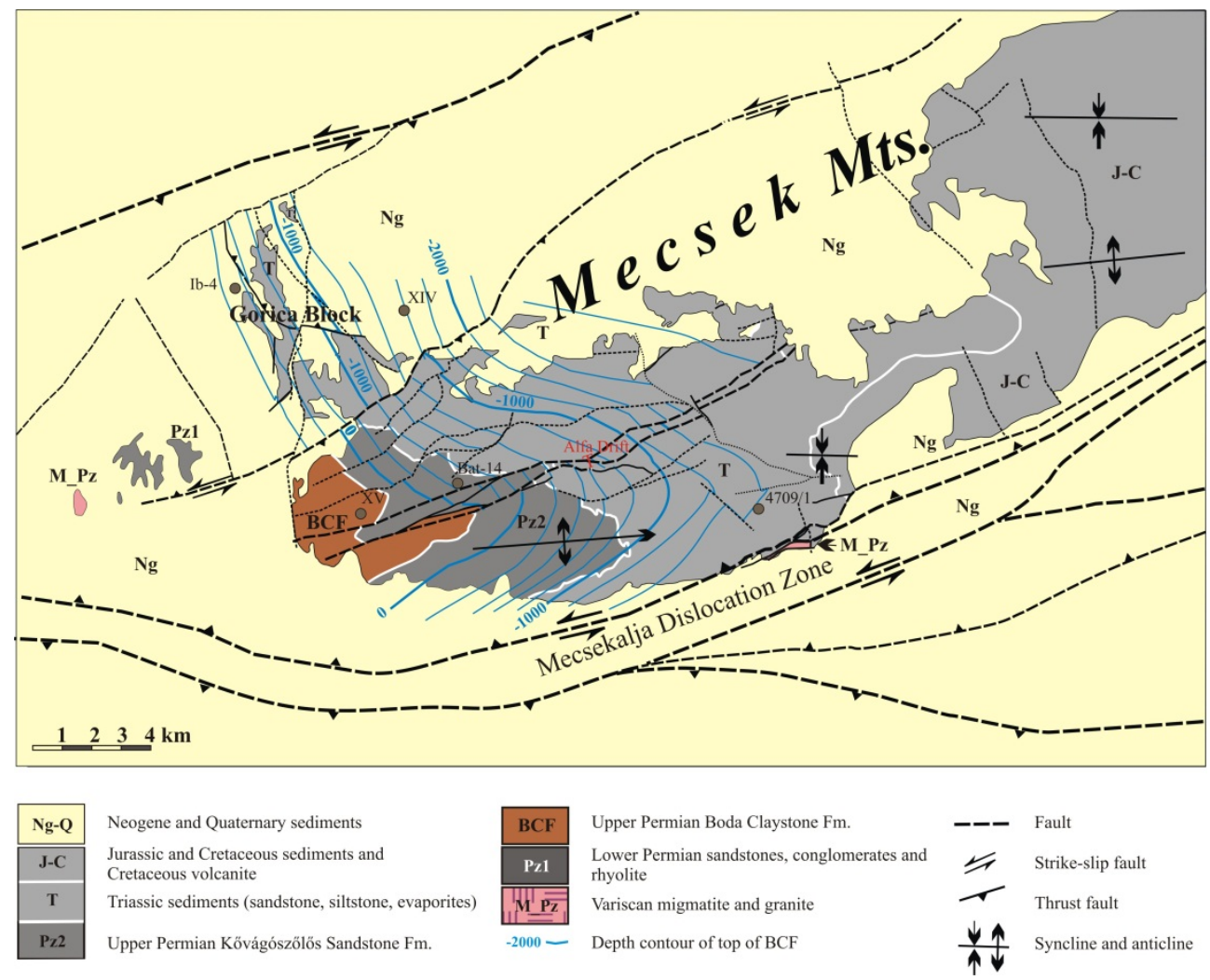

Figure 4. Geological map with depth contour of the top of the Boda Claystone Formation and locations of studied objects (boreholes: Bat-14, Ib-4, Alfa Drift) after [13] 


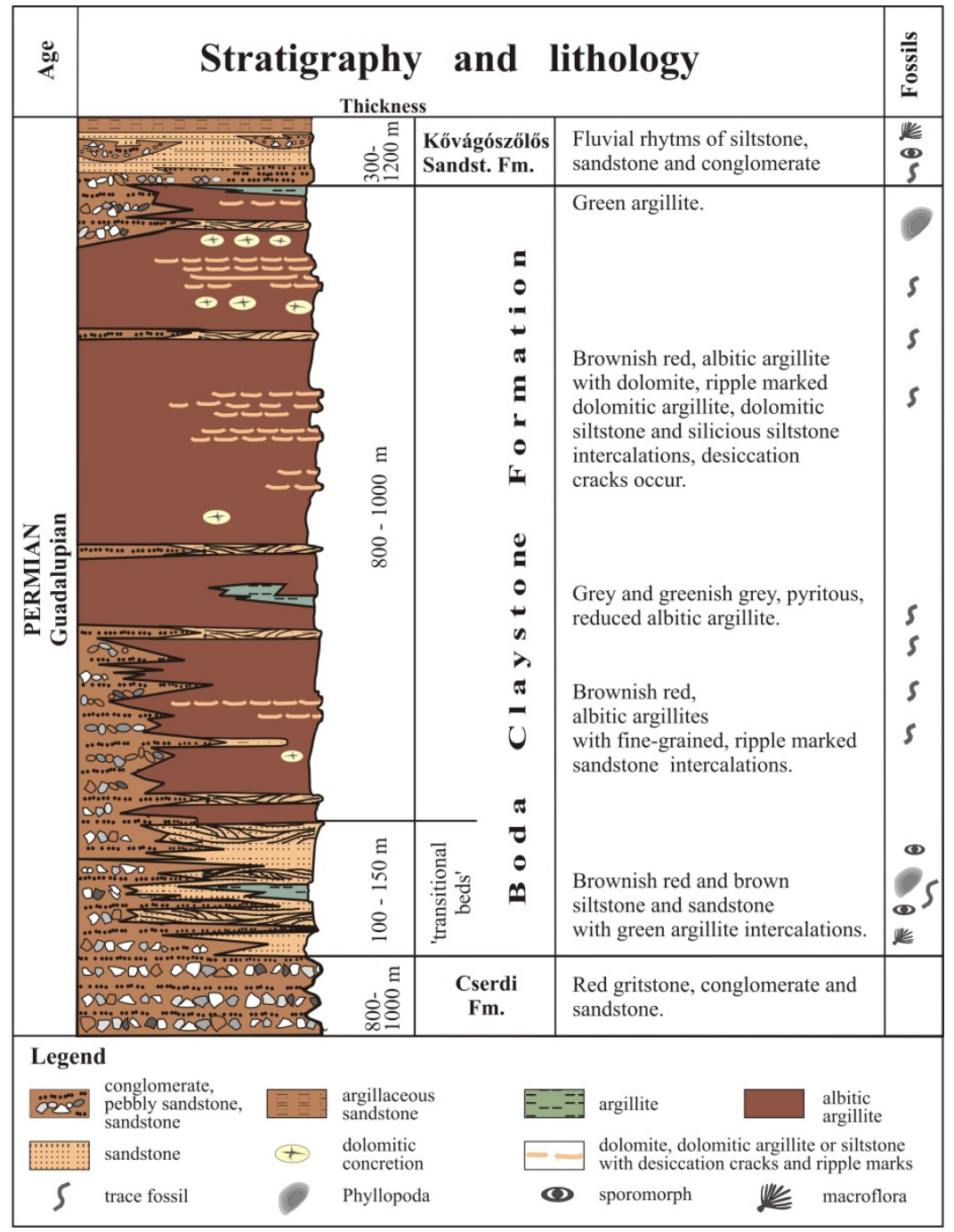

Figure 5. Idealised lithological column of Boda Claystone Formation [13]

On the basis of data of boreholes and geological mapping BCF is known in an area of 150 $\mathrm{km}^{2}$. Within this area approximately $15 \mathrm{~km}^{2}$ can be found on the surface in W Mecsek Mountains (see Figure 4). Two distribution areas of BCF are known in W Mecsek Mountains: i/ perianticlinal structure of the W Mecsek Mountains; ii/ so called Gorica block. In the Gorica block outcrop of BCF is not known; in this block only the borehole Ib-4 recovers sequence of BCF in significant thickness (between 494,2 and $709 \mathrm{~m}$ ) (Figure 4).

On the basis of the deep drillings total thickness of BCF is estimated to be about 700-900 m (in perianticlinal structure of the $\mathrm{W}$ Mecsek Mountains) whereas according to our 
knowledge its thickness is smaller in the Gorica block (about $350 \mathrm{~m}$ ). The sediments of the $\mathrm{BCF}$ are dominantly red and reddish brown in color, reflecting the dominantly oxidizing nature of the depositional and early diagenetic environments [14-18] (Figure 6).

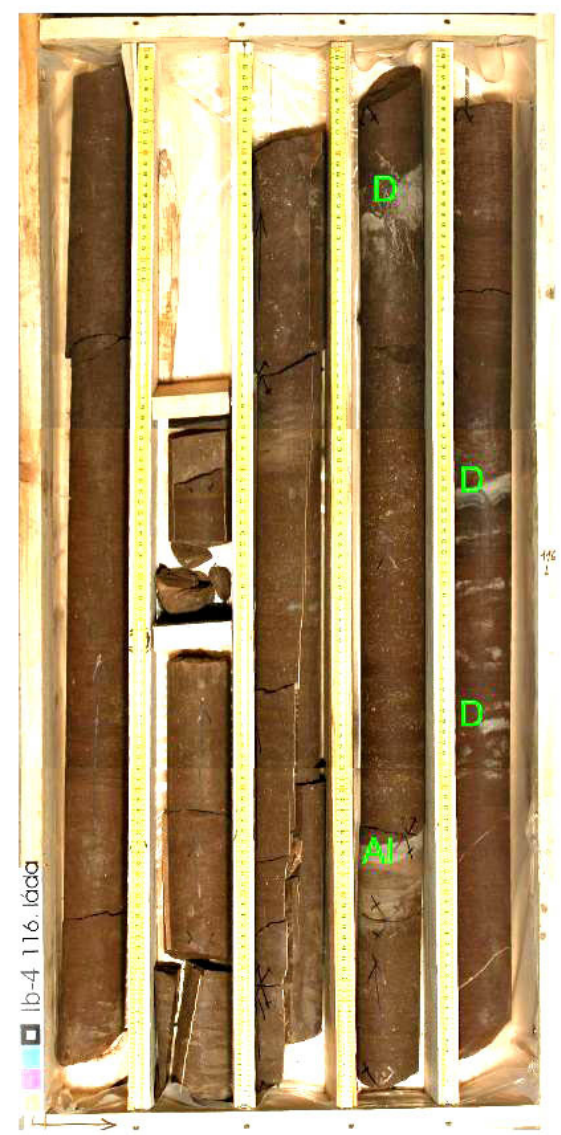

Figure 6. Reddish brown albitic analcite-bearing claystone with interbedded aleurolite (Al) and dolomite (D) layers (Ib-4, 591-596 m).

The BCF was deposited in a shallow-water lacustrine environment (playa mudflat, playa lake), under semi-arid to arid climatic conditions. According to our present-day knowledge the middle thickest unit of the BCF has only one reduce interbedding (greyish black albitic claystone containing pyrite and finaly disseminated organic matter), its tickness is about 3-4 $\mathrm{m}$. However, several reduce thin layers (green, greenish-gray claystone, siltstone) can be observed in its lower and upper transitional zones (Figure 5).

On the basis of mineralogical investigation with X-ray diffraction (XRD), differential thermal analysis (DTA), and electron microscopy (EMP), the main rock-forming minerals of the BCF are: clay minerals (absolute dominant are illite-muscovite and chlorite; smectite, kaolinite, 
vermiculite and mixed-layer clay minerals were identified in considerable amounts), authigenic albite, quartz, carbonate minerals (calcite and dolomite) and hematite [16-19]. In addition, barite, anhydrite, authigenic K-feldspar and detrital constituents (muscovite, biotite, chlorite, zircon, rutile, apatite, ilmenite, Ca-bearing plagioclase) were always also identified in trace amounts. The authigenic albite is present as albite cement (typical of all rock types of formation), albite and carbonate-lined disseminated irregular white voids (typical of albitic claystone) and albite replacement of detrital feldspars in sandstone beds [16-17, 19].

Six main rock types of BCF can be defined based on mineralogical, geochemical and textural considerations, namely, albitic claystone, albitolite, "true" siltstone, dolomite interbeddings, sandstone, and conglomerata [13, 15-17, 19,]. Their mineral compositions are shown in Table 3.

\begin{tabular}{|c|c|c|c|c|c|}
\hline Rock types & $\begin{array}{c}\text { clay } \\
\text { minerals } \\
(\text { wt } \%)\end{array}$ & $\begin{array}{c}\text { authigene } \\
\text { albite } \\
(\text { wt } \%)\end{array}$ & $\begin{array}{c}\text { quartz } \\
(\text { wt } \%)\end{array}$ & $\begin{array}{c}\text { carbonates } \\
(\text { wt } \%)\end{array}$ & $\begin{array}{c}\text { hematite } \\
(\text { wt \%) }\end{array}$ \\
\hline $\begin{array}{c}\text { albitic } \\
\text { claystone }\end{array}$ & $20-50$ & $20-50$ & $5-10$ & $\sim 10$ & $7-10$ \\
\hline albitolite, & $<25$ & $>50$ & $<10$ & 10 & $5-6$ \\
\hline $\begin{array}{c}\text {,true" } \\
\text { siltstone }\end{array}$ & approx. 10 & $>35$ & $>25$ & approx. 10 & 5 \\
\hline $\begin{array}{c}\text { dolomite } \\
\text { interbeddings }\end{array}$ & 10 & $30-40$ & 5 & $35-50$ & 5 \\
\hline sandstone & 5-traces & $25-40 *$ & $20-30$ & $5-20$ & 5 -traces \\
\hline
\end{tabular}

* detrital feldspar + authigene albite

Table 3. Mineral compositions of the main rock types in Boda Claystone Formation

This mineralogical composition is typical of in perianticlinal structure of the W Mecsek Mountains. The principally dominant rock type of the formation is albitic claystone.

$\mathrm{BCF}$ recovered from borehole $\mathrm{Ib}-4$ (Gorica block) differs in its mineralogical composition. This succession of BCF contains abundant analcime in significant amounts in addition to the above minerals, in a range between 8 and $25 \mathrm{wt} \%$; (typical examples are shown in the table below).

\begin{tabular}{|c|c|c|c|c|c|c|}
\hline $\begin{array}{c}\text { Samples } \\
\text { Ib-4 }\end{array}$ & $\begin{array}{c}\text { clay } \\
\text { minerals }\end{array}$ & $\begin{array}{c}\text { authigene } \\
\text { albit }\end{array}$ & analcime & quartz & carbonates & hematite \\
\cline { 2 - 7 } & \multicolumn{7}{|c|}{ wt \% } \\
\hline $527,2 \mathrm{~m}$ & 42 & 8 & 12 & 13 & 18 & 6 \\
$538,7 \mathrm{~m}$ & 34 & 7 & 16 & 28 & 10 & 5 \\
$560,64 \mathrm{~m}$ & 43 & 16 & 20 & 3 & 10 & 8 \\
\hline
\end{tabular}

Table 4. Mineral compositions of typical samples taken from Ib-4 borehole in Gorica block 
In the Gorica block the same rock types can be defined based on mineralogical, geochemical and textural considerations as in the perianticlinal structure of the W Mecsek Mountains.

The Boda Claystone Formation is divided into three main sections [13]; for the characterization of the units see Figure 5. In the Middle Cretaceous on the basis of thickness of overlying strata in perianticlinal structure of West Mecsek Mts. the BCF was located at least at 3,5 to 4,0 km burial depth. Data determined in area of the perianticlinal structure of the W Mecsek Mountains point to late or deep diagenesis, max. $200-250{ }^{\circ} \mathrm{C}$ according to illite and chlorite crystallinity as well as vitrinite reflectance [17]. Higher illite and chlorite crystallinity is determined in core samples of the deep drilling Ib-4 (Gorica block), suggesting that BCF in Gorica block underwent lower grade diagenesis.

There were various stages of exploration and detailed characterisations of BCF. For a period even an Underground Research Laboratory was established and had been maintained in a depth of $1050 \mathrm{~m}$ below ground level $(1994-1998)$. The results of studies performed there are collected in various reports. The data had been analysed from the aspects of criteria for establishing a waste disposal site, the main conclusions of them are compiled in a Digest [20]. The most important conclusions were presented also at one of the "Clay Club"s conferences [21].

\subsection{Specific characterisations - samples}

In a further stage of investigations selected Boda Claystone samples were used for measurements performed by applying directly radionuclides to obtain informations on the isolation properties of the rock against long half life-time isotopes.

Sorption and diffusion studies were performed by using fission isotopes and one of the most relavant acitnoide element, uranium. Among others samples from Delta-9, Bat-14 and IB-4 borecores were selected.

Delta-9 deep drilling is located in Alfa Drift at the $1050 \mathrm{~m}$ depth below ground level, it is nearly a horizontal borehole; Bat-14 was drilled near the outcrop of $\mathrm{BCF}$, here the formation is covered by $25,5 \mathrm{~m}$ thick Quaternary sediments, and $\mathrm{Ib}-4$ borehole starts also from the surface in the Gorica block, and the studied samples were collected from a distant depth 570 $\mathrm{m}$ (for their locations see Figure 4). Some specific studies on these samples are presented in the following paragraphs, the results of measurements with radionuclides are presented afterwards.

\subsubsection{High resolution SEM with electron diffraction}

These measurements were performed on samples from borehole IB-4 $(570 \mathrm{~m})$. A SEM/Electrondiffraction image is shown in Figure 7 from a small area of the sample. The corresponding general mineral composition is shown in Table 5.

Figure 7 illustrates the structure of the sample. Very small crystals originated from the secondary processes form the consolidated clay rock. It is also shown that within small 
distances the composition may change significantly (see e.g the lower right corner - it is more abundant in analcime than the rest). Parallel porosity measurements were also performed from the same regions. It was found that the porosity at the analcime rich bottom right corner is ca. $1.5 \%$, whereas in the upper part is $3.5 \%$. In contrast the portion of calcite is larger in the top regions

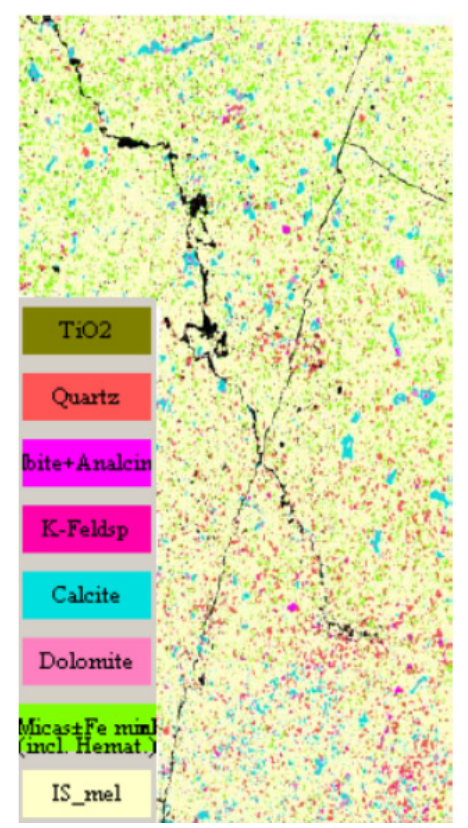

Figure 7. Mineral composition obtained from a SEM \& electron diffraction image of a $5 \times 2.5 \mathrm{~mm}$ section from IB-4 (570 m) sample (IS mel: mixed illite-smectite. The image was recorded in ERM, Poitiers, France)

\begin{tabular}{|c|c|}
\hline Mineral & $\begin{array}{c}\text { Content } \\
(\%)\end{array}$ \\
\hline $\begin{array}{c}\text { Illite - } \\
\text { muscovite }\end{array}$ & 33 \\
\hline Chlorite & 2 \\
\hline Smectite & 2 \\
\hline Analcime & 23 \\
\hline Albite & 12 \\
\hline Quartz & 11 \\
\hline Calcite & 9 \\
\hline Dolomite & 1 \\
\hline Hematite & 7 \\
\hline
\end{tabular}

Table 5. Average mineral composition of the IB-4 $(570 \mathrm{~m})$ sample determined by quantitative XRD analysis 


\subsubsection{Mössbauer spectroscopy}

Oxidation and coordination states of iron can conveniently be studied by Mössbauer spectroscopy. The method can also be used to analyse iron-bearing minerals. (Corresponding Mössbauer parameters of over 400 iron containing minerals are collected in the handbook [22].) Boda Claystone contains also iron-bearing minerals in considerable amounts (hematite, clay minerals), thus samples can also be analysed, and some processes occured in the formation of the rock can be traced.

The ferric iron oxide, hematite exhibits a magnetically split characteristic sextet. Iron in the clay minerals displays two-line doublets in the spectra. Doublets of $\mathrm{Fe}^{2+}$ and $\mathrm{Fe}^{3+}$ states can clearly be distinguished, their positions are different. Two examples are shown below, in Figures 8 and 9. The effect of weathering can be tracked in Figure 8 in which spectra of samples collected from layers close to the surface (below the $25 \mathrm{~m}$ Quaternary sediments) are shown for Bat-14 borehole. The very right peak in the spectra belongs to the $\mathrm{Fe}^{2+}$ ions in chlorite mineral [22]. It is seen that the intensity of this peak inreases in correspondence with the sampling depth. I.e. clay minerals in the top layers are much abundant in $\mathrm{Fe}^{3+}$ whereas in the deeper layers $\mathrm{Fe}^{2+}$ starts to dominate in clay minerals. On the other side, the amount of hematite (marked with $\mathrm{H}$ in the right side spectra) practically is the same in each sample. Thus it can be concluded that $\mathrm{Fe}^{2+} \rightarrow \mathrm{Fe}^{3+}$ oxidation had taken place in the layers close to the surface, in other word the process of weathering is reflected in the $\mathrm{Fe}^{2+} / \mathrm{Fe}^{3+}$ change.

The conditions controlling the formation of minerals can be deduced from specra of Figure 9. Boda Claystone is described in the previous parts of this chapter as a rock which was formed essentially under oxidizing conditions. However a few exceptional strata also exist.

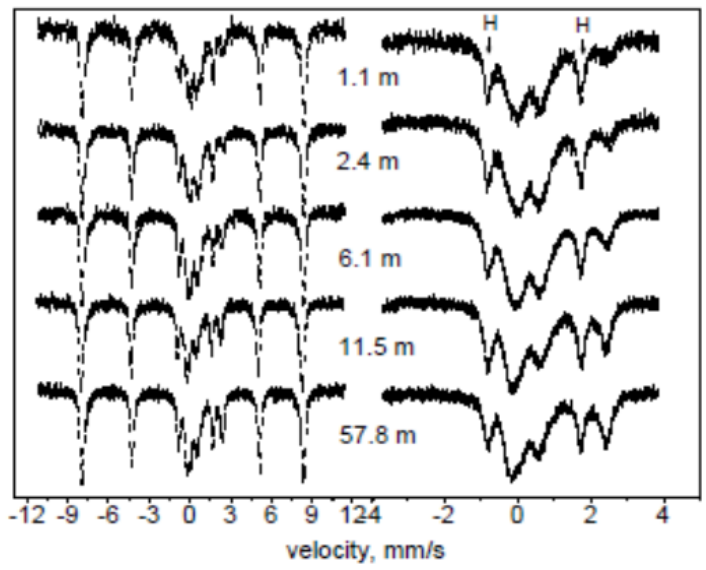

Figure 8. Mössbauer spectra on samples collected from borehole BAT-14. The main iron bearing mineral is hematite (left spectra). Effect of weathering is shown in the right side spectra, approaching to the surface $\mathrm{Fe}^{3+} / \mathrm{Fe}$ ratio increases in the clay mineral (chlorite) 


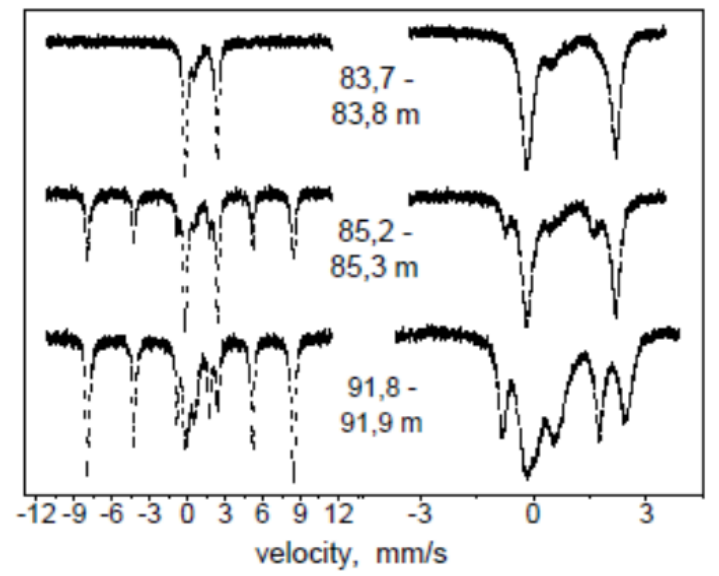

Figure 9. Crossing a reducing zone at $83.7 \mathrm{~m}$ in Delta- 9 borehole. Iron is present only in $\mathrm{Fe}^{2+}$ form in chlorite. Hematite starts to appear in other distances.

For example Delta-9 borehole crosses a few meter thick layer in which reducing conditions controlled the formation of the minerals. This layer is located ca. at the $83-84 \mathrm{~m}$ distance from the commencement of the borehole (Note: the borehole was drilled at the $1050 \mathrm{~m}$ depth.) The overwhelming part of iron is present in $\mathrm{Fe}^{2+}$ form in chlorite - hematite is not present at all in the top spectrum of Figure 9. By moving apart a few meters from this layer hematite appears and its presence becames prevailing by moving even farther.

Both examples show that iron ions located in the layered clay minerals are sensitive to the change of redox conditons and they can be used as indicators to monitor the alterations in them. Further description and interpretation of these measurements can be found in [23].

\subsubsection{Reduction/oxidation studies from voltammetry of microparticles}

The reduction/oxidation properties of rocks and minerals can also be studied by voltammetric measurements. Even small amounts of them can be analyzed by voltammetry of microparticles. Samples shown in Figure 9 were also characterised at the LCPME - CNRS, Nancy, France). For illustraton, Figure 10 displays some cyclic voltammograms obtained on samples collected from Delta 9 borehole.

The results of voltammeric measurements are in good correspondence with the Mössbauer analysis as Figure 10 displays. High anodic current (A1 peak at $0.65 \mathrm{~V}$ - relative to standard calomel electrode) could be detected which can be attributed to extended oxidation of $\mathrm{Fe}^{2+}$ ions on the sample formed under reducing conditions (collected from $83.7 \mathrm{~m}$ position). On the other two samples formed under oxidative environment reduction of iron ions ions can be observed ( $\mathrm{C} 1$ peak probably corresponds to reduction of ions in the dissolved ions, $\mathrm{C} 2$ at $-0.45 \mathrm{~V}$ to the reduction of ferric ions in the clays and C3 at $-0.74 \mathrm{~V}$ is for ferric ions in hematite). More extended description of the method, samples and measurements can be found in [24]. 


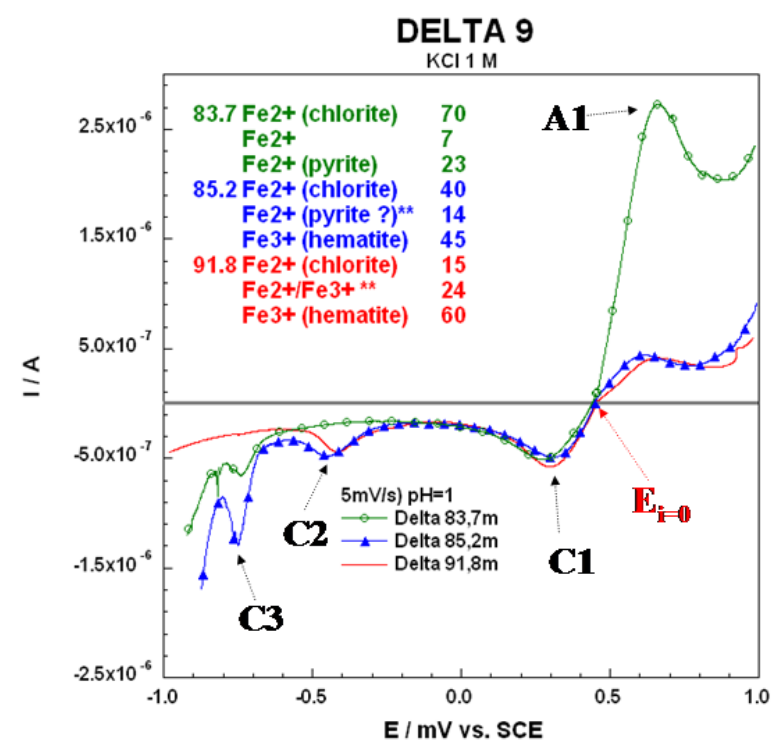

Figure 10. Cyclic voltammograms obtained on samples collected from Delta-9 borehole. The numbers in the top left corner represent the relative amounts of iron bearing minerals extracted from Mössbauer spectra of Figure 9. A1 stands for anodic, C1, C2 and C3 for cathodic peaks, $\mathrm{E}_{\mathrm{i}=0}$ is the zero potential. (The voltammograms were measured at LCPME Nancy, France)

\subsection{Studies with long life-time radionuclides}

\subsubsection{Sorption measurements}

In the first stage of investigations sorption of radionuclides, mostly fission products, were investigated on various types of samples. Namely $\mathrm{K}_{d}$ values were determined for ${ }^{125} \mathrm{I},{ }^{137} \mathrm{Cs}$, ${ }^{60} \mathrm{Co}$ and ${ }^{85} \mathrm{Sr}$ on various Boda Claystone samples collected from boreholes drilled in the $1050 \mathrm{~m}$ depth exploratory tunnel. Measurements were performed with $2 \mathrm{~g}$ amounts of crushed samples. Radionuclides were added in trace amounts to $20 \mathrm{ml}$ volume of ground water $\left(10^{-5}-10^{-3} \mathrm{~mol} / \mathrm{L}\right)$. $\mathrm{K}_{\mathrm{d}}$ values were determined by using Eq. (1). There was a scatter in the results depending of the samples, for ${ }^{125} \mathrm{I} 0.2-2.0$, for ${ }^{85} \mathrm{Sr} 60-120$, for ${ }^{137} \mathrm{Cs} 600-5000$ and for ${ }^{60} \mathrm{Co} 1200$ - 15000 values were determined. Concentration dependence of the sorption was also measured by diluting the tracer isotopes with inactive (natural) isotopes. Sorption of caesium showed a regular behaviour, the constants of a non-linear Freundlichtype isotherm could also be determined. Similar results could not be obtained with $\mathrm{Sr}^{2+}$ and $\mathrm{CO}^{2+}$, both ions have low solubility in the applied ground water, they easily form precipitates $\left(\mathrm{SrCO}_{3}\right.$, and $\left.\mathrm{Co}(\mathrm{OH})_{2}\right)$. Further details and results are described in [25].

It should be mentioned that similar sorption measurements were also performed on samples originated from another facies of Boda Siltstone, rich in analcime component originated from IB-4 borehole (see Figure 7 and Table 5). In these measurements non-radioactive natural isotopes were applied with higher concentrations, their amounts were determined 
by atomic absorption spectroscopy measurements. The results are in good correspondence with those obtained with radioisotopes [26]. The obtained $\mathrm{K}_{\mathrm{d}}$ values might be applied for the further evaluation of the isolation properties of the rock against migration of radionuclides by using Eq. (2).

In relation with Eq. (2) it was already pointed out that principally it decribes the relative retardation of the velocity of migration of radionuclides compared to the velocity of hydraulic flow. The equation is primarily valid for cations, tending to adsorb on negatively charged clay minerals in the aqueous media. Negatively charged species hardly sorb as is reflected for example with the mentioned low $\mathrm{K}_{\mathrm{d}}$ value of ${ }^{125} \mathrm{I}$. Further on, Boda Claystone has small porosity (1-3\%) and the water permeability also lies in an extremely low value region $\left(10^{-20}-10^{-23} \mathrm{~m}^{2}\right)$ [27]. Thus, the velocity if hydraulic flow can also be practically negligible. Consequently, there are at least two reasons that the velocity of spreading of negatively charged anionic species cannot be estimated by using Eq. (2). One reason is that the $v_{g} w$ term it close to zero in the equation, the other reason is that anionic species do not sorb on clay minerals.

In order to obtain reliable information on the migration of negatively charged anionic species another option should be applied, namely to perform direct diffusion measurements.

\subsubsection{Measurement of the diffusion coefficient of anionic species and HTO}

To obtain approximately reliable information on the diffusion of radionuclides it is advised to use compact rock samples with their preserved consolidated structure. Various arrangements can be used. One option is to use a simple measuring arrangement, the breakthrough cells as mentioned in Section 2.3. The effective diffusion coefficients can be experimentally determined by using Eq (3).

It is also possible to collect information on the permeability and self diffusion of water itself by using a particular radiotracer, that is tritiated water, HTO.

Break-through measurements were carried out with HTO and with anionic long life-time fission product tracers $\left({ }^{99} \mathrm{TcO}_{4}^{-}\right.$and $\left.{ }^{125} \mathrm{I}\right)$ and additionally, with $\mathrm{H}^{14} \mathrm{CO}_{3}^{-}$. The compartments of c.a. 90 volume in the break-through cells were filled with ground water. The studied 8 $\mathrm{mm}$ thick borecore disc samples were obtained from the $570 \mathrm{~m}$ depth in the IB-4 borehole. Ground water in one side of the compartments was separately spiked with tracer amounts of the respective isotopes (10 $\mathrm{MBq} \mathrm{HTO}, 6.2 \mathrm{MBq}^{99} \mathrm{TcO}_{4}^{-}$and $8 \mathrm{MBq} \mathrm{H}^{14} \mathrm{CO}_{3}^{-}$, respectively). These radionuclides emit $\beta$-radiation, the activities in small amounts of samples (10 microliter) taken regularly from the compartments were determined liquid scintillation detection. As an illustration, the measurements performed in a series with $\mathrm{H}^{14} \mathrm{CO}_{3}^{-}$are shown in Figure 11 (next page).

The top part of the figure shows that after a minor decrease the activity (i.e. the concentration of $\mathrm{H}^{14} \mathrm{CO}_{3}{ }^{-}$) is constant. The bottom part displays the break-through, the appearance and the increase of the concentration of the radionuclide in the ground water in the compartment on the other side of the sample disc. Note that only c.a. $2 \%$ of the total amount of $\mathrm{HCO}_{3}^{-}$ 
penetrates through the $8 \mathrm{~mm}$ thick disc within a year. The delay in the commencement of the break through indicates the interaction between the solute and solid phases. The intercept on the horizontal axis is c.a. 220 days, this is the value of $\alpha$ (retention coefficient) in Eq. (3).

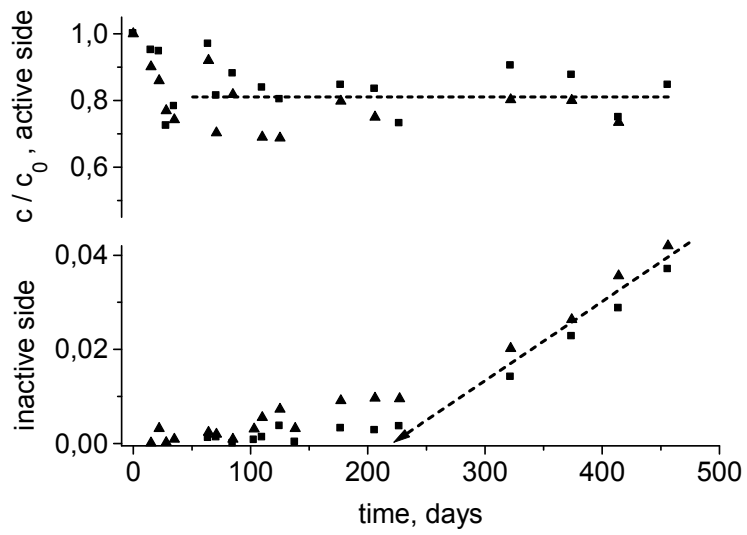

Figure 11. The relative activities of ${ }^{14} \mathrm{CO}^{2-}$ in the active (top) and originally inactive (bottom) compartments of the break-through cell at $\mathrm{pH}=12$ on two samples (marked with squares and triangles).

The delay in the break-through can probably be attributed to the exchange of radiocarbon to the carbonates in minerals of solid phase. Namely, the mesurements presented in Figure 11 were performed at $\mathrm{pH}=12$. At this $\mathrm{pH}$ the $2 \mathrm{HCO}_{3}^{-} \leftrightarrow \mathrm{CO}^{2-}+\mathrm{H}_{2} \mathrm{O}+\mathrm{CO}_{2}$ equilibrium is shifted to the right, ie. $\mathrm{CO}_{3}{ }^{2-}$ ions prevail over the hydrocarbonates, and some of the ${ }^{14} \mathrm{CO}_{3}{ }^{2-}$ ions may be exchanged from the solution to the solid phase with carbonates in calcite (dolomite). The main data extracted from the measurements and evaluated in correspondence with Eq (3) are collected in Table 6. Further experimental details, description of samples and measurements performed with the $\beta$-emitting isotopes can be found in [28].

\begin{tabular}{|c|c|c|}
\hline $\begin{array}{c}\text { Migrating } \\
\text { species }\end{array}$ & $\begin{array}{c}\text { Deff } \\
10^{-12} \mathrm{~m}^{2} \mathrm{~s}^{-1}\end{array}$ & $\alpha$ \\
\hline $\mathrm{HTO}$ & 14 & $\sim 0$ \\
\hline${ }^{114} \mathrm{CO}^{-}$ & $\sim 1$ & $\sim 0^{\mathrm{a}}$ \\
& $\sim 1$ & $1.5^{\mathrm{b}}$ \\
\hline${ }^{99} \mathrm{TcO}_{4}^{-}$ & $\sim 1$ & $\sim 0$ \\
\hline${ }^{125} \mathrm{I}^{-}$ & $\sim 8-14^{\mathrm{c}}$ & $0.3-1.3^{\mathrm{c}}$ \\
\hline
\end{tabular}

Remarks: measured at $\left(^{\mathrm{a}}\right) \mathrm{pH}=8$ and $\left({ }^{\mathrm{b}}\right) \mathrm{pH}=12$

$\left({ }^{c}\right)$ values from different type measurements (see in [28])

Table 6. Effective diffusion coefficients and retention factors ( $\alpha$ in Eq. 3 ) of neutral (HTO) and anionic migrating radionuclides

As for investigations related to the diffusion of iodide anion it should be mentioned that several more extended measurements have also been performed by using $\gamma$-emitting ${ }^{125} \mathrm{I}$ isotope (35.5 keV with half life-time only 60.2 days). The $\gamma$-radiation allows a more easy 
detection of the radiating isotope, for example presence and acitivity of ${ }^{125} \mathrm{I}$ in solid samples can directly be measured. The migration behaviour is expected to be the very same as the long half life time fission product ${ }^{129} \mathrm{I}\left(1.710^{7}\right.$ years).

Two additional types of diffusion measurements were performed with ${ }^{125}$. The in-diffusion was measured from spiked groundwater into borecore samples, and concentrations of iodine were determined in slices cut from the end of the solid borecore. In another arrangement the „in situ" conditions were modeled by placing the borecore samples under 100 bar pressure at $50{ }^{\circ} \mathrm{C}$ during the period of the measurements. These conditions correspond to the values of the ambient pressure and temperature in a rock located in $1000 \mathrm{~m}$ depth (characterising e.g. the former exploratory alpha drift). Two sets samples were used for these measurements, a few one was kept under these conditions for 118, another few for 340 days, the iodine contents were measured in the solid slices of sample borecore afterwards.

The results of the three types of measurements of diffusion coefficient of iodide (the breakthrough, the in-diffusion and the „in situ”) were in good correspondence with similar values. Further experimental details and evaluation are described in [29].

As for the general evaluation of measurements with anions, data of Table 6 are in good correlation with the expectations. Namely, water and the anionic iodide exhibit high mobility, with similar $D_{\text {eff }}$ values. This reflects the lack of interactions with clays. Hydrocarbonate and technetate anions move more slowly. In the first instance some interaction (exchange) may take place between carbonate ions in the solution and in the solid phase. Technetate may move slower due to the larger radius of the hydrated anion. Further on, it is worth comparing these values with the self diffusion coefficients of ions in strong aqueous electrolytes. For this end, the Bruggeman relation should be recalled which establishes connection between the measured effective diffusion coefficient $\left(D_{\text {eff }}\right)$ and the self diffusion constant $\left(D_{s}\right)$ through the porosity $(\varepsilon)[30]$ :

$$
D_{e f f}=\sqrt{\varepsilon^{3}} \cdot D_{s} .
$$

The self diffusion constant for ions in aqueous electrolytes is $1.710^{-9} \mathrm{~m}^{2} \mathrm{~s}^{-1}$ [31]. Taking into account the $1.5-3 \%$ porosity, the measured $D_{\text {eff }}$ values correlate well to the self-diffusion constant values characterising the electrolytes in aqueous soulutions. The similarity of the compared values reflects that there is no significant interaction between the anionic component and the minerals of the clay - they diffuse through the rock without any interaction with the pore walls (provided the $\alpha$ rock capacity factors are close to zero).

As an upper limit for the velocity of the migration of long life-time isotopes the obtained $10^{-12} \mathrm{~m}^{2} \mathrm{~s}^{-1}$ can be considered. (The cations migrate more slowly since they interact and may became sorbed on the minerals.) As a very rough approximation the

$$
x \approx \sqrt{D_{\text {eff }} t}
$$

distance (radius) - time relation can be considered within which the radionuclides spread during their life-time. Inserting the long half life-times values into this approaching equation 
the order of magnitude of migration distance can be estimated. For illustration, for ${ }^{99} \mathrm{TcO}_{4}^{-}$(half life-time $2.110^{5}$ years) ca. $1.4 \mathrm{~m}$ is the distance, for the longer lifetime ${ }^{129} \mathrm{I}$ (1.7 10 ${ }^{7}$ years) $\sim 30 \mathrm{~m}$ is the distance of spreading within one half lifetime period in Boda Claystone media. These distance values should be considered with precaution. First, only one half lifetime period was considered, the amount of radiation emitting isotopes will be only halved within this period. The second point is our starting precondition, namely the hydraulic flow was neglected. Thus, in real cases the distances of migration can be significanly longer.

Some properties of the other clayrock types considered for final disposal for nuclear wastes were also briefly mentioned in previous section 3.1 (Boom Clay, Opalinus Clay, and Callovo-Oxfordian argillite). Here, at the end of the present section dealing with diffusion constant measurements on Boda Claystone samples, a reference should also be given to an overview, which provides a detailed compilation and description of recent diffusion studies performed in the framework of the EC FUNMIG IP project on all the mentioned four types of clayrocks [32]. In general diffusion data obtained on Boda Claystone suit well within those collected on the other three types of rocks which had been extensively studied and characterized in the project.

\subsubsection{Break-through studies with uranium}

In the preceeding sections mostly sorption and diffusion properties of fission products were discussed on Boda Claystone samples. To consider the behaviour and interactions of the long life-time actinide components with minerals in Boda Claystone the major component of the high level nuclear wastes, uranium was also investigated in break-through experiments. Uranium is similar to neptunium in respect with the occurence of various oxidation states (as was shown for $\mathrm{Np}$ in Figure 2.) Depending on the Eh - $\mathrm{pH}$ conditions uranium may be stabilized either in cationic, or in anionic form or as stable neutral precipitate. The U-C-O-H diagram is shown - it can be applied for carbonate containing rocks and in correspondence hydrocarbonate contaning ground water, which is the case for Boda Claystone. Stability regions of iron are also shown and separated in black dashed lines (Figure 12 - based on [4]).

The life cycle of the disposal site is also shown in blue (similarly to Np in Fig 2). At the start uranium (or a part of it) may be dissolved in form uranyl ions $\left(\mathrm{UO}_{2}{ }^{2+}\right)$ into the ground water. This species is a cation and prefers to ad- or chemisorb on the clay minerals. After having the site closed the potential decreases, the $\mathrm{pH}$ increases - neutral $\mathrm{UO}_{2} \mathrm{CO}_{3}$ may precipitate. In a subsequent stage with the further increase of $\mathrm{pH}$ negatively charged carbonates can be formed which tend to migrate in the aqueous phase. In the final stage with the decrease of potential the reduction prevails and stable $\mathrm{UO}_{2}$ forms from the various migrating $\mathrm{U}(\mathrm{VI})$ uranyl carbonate species (shown as the orange encircled area in Figure 12). In the encircled region $\mathrm{Fe}^{2+} \leftrightarrow \mathrm{Fe}^{3+}$ redox processes may also proceed, maybe they can be coupled with the mentioned $\mathrm{U}(\mathrm{VI}) \rightarrow \mathrm{U}(\mathrm{IV})$ reduction.

In the corresponding break-through experiments the ground water was saturated with uranyl acetate (using uranium with natural isotope composition, dominant ${ }^{238} \mathrm{U}$ with ca. $1 \%{ }^{235} \mathrm{U}$ ). The changes of activities of uranium were measured in the compartments of the break-through cells. Furthermore, the distribution of uranium along the path of migration in the bore core 


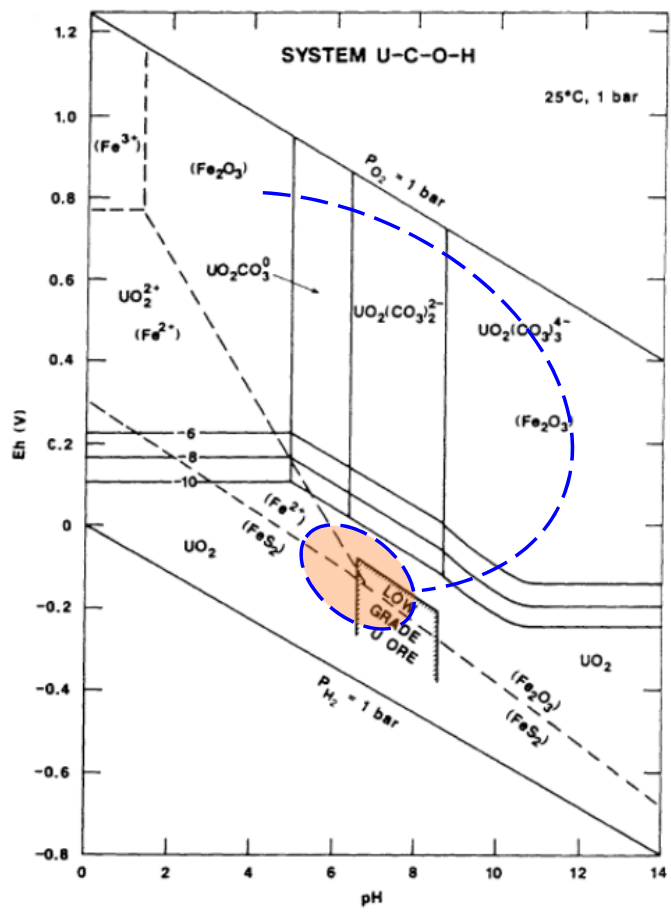

Figure 12. The Eh-pH Pourbaix-diagram of uranium. The dashed line represents the possible changes during the life cycle of the repository, the encircled region might be the final stage.

samples was also determined by high sensitivity laser ablation ion-coupled mass spectrometry (LA-ICP-MS) after finishing the experiments and dismounting the break-through cells. The change of concentration (activity) of uranyl ions in dependence of time is shown in Figure 13. Note the long time interval, the samples were kept in the cells for ca. five years.

Primarily the depletion of uranium is seen in the starting solution in Figure 13. In the very first period a sudden drop takes place, c.a. $20 \%$ of uranium disappears from the solution, most probably due to precipitation of carbonates via the $\mathrm{HCO}_{3}{ }^{-} \leftrightarrow \mathrm{CO}_{3}{ }^{2-}$ equilibrium in the solution, where almost all the carbonates are consumed. After having this fast process finished the amount of uranium had been stabilised for c.a. one year at the $70-80 \%$ level of the original concentration. Later on the starting solution is considerably depleted in uranium. Uranium is apparently trapped in the solid borecore disc, simultaneous measurements on liquid samples does not show any sign of through diffusion. Negligible increase of the amount of uranium is detected in samples taken from the opposite compartment of break-through cell (bottom curve in the Figure).

In correspondence, the LA-ICP-MS measurements directly prove the event of trapping. A typical distribution of concentration (intensity) of uranium is shown in Figure 14, which displays the distribution of uranium along the migration path, crossing the borecore dics. (Notice the logarithmic scale on the vertical intensity/concentration axis.) 


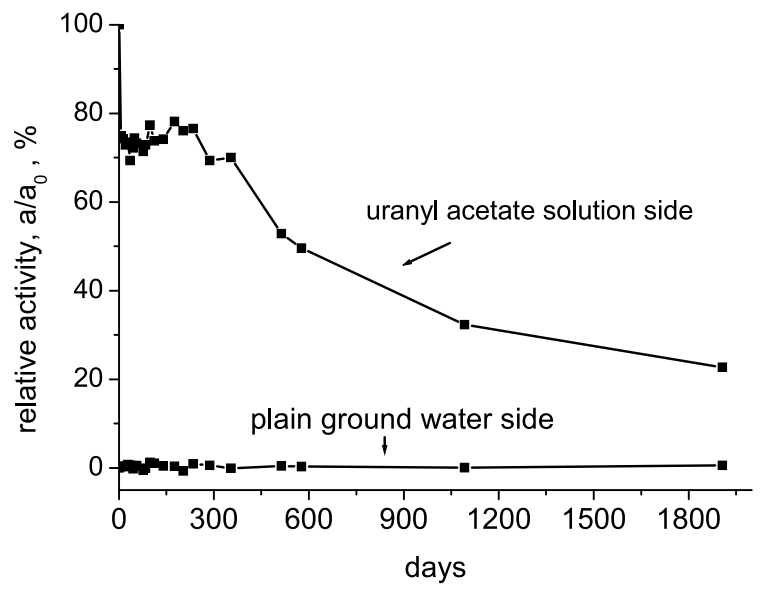

Figure 13. Changes of concentations of uranium in the two compartments of a break-through cell during ca. 5 years. Top curve is the original solution, the bottom curve is for the opposite compartment.

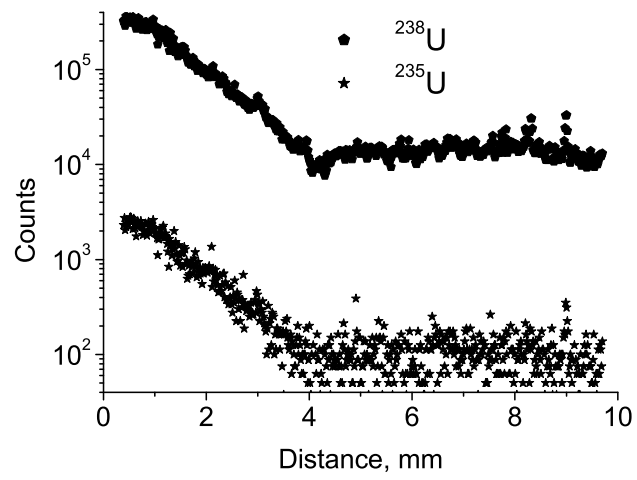

Figure 14. ${ }^{238} \mathrm{U}$ and ${ }^{235} \mathrm{U}$ contents measured in the sample after finishing the 5 year break-through experiment. The left side of sample contacted the uranyl solution. Note the logarithmic scale on the vertical axis.

The figure illustrates the sensitivity of the method, even the minor uranium component, ${ }^{235} \mathrm{U}$ (a few ppb in the sample, $\sim 1 \%$ in the natural uranium component), can convincingly be measured. It is seen that the characteristic longest migration distance was only c.a. $4 \mathrm{~mm}$ during the five years duration. (The horizontal sections between 4 and $10 \mathrm{~mm}$ distances refer to the ${ }^{238} \mathrm{U}$ and ${ }^{235} \mathrm{U}$ contents present originally in the sample before the start of measurements.) At the first approximation the drops of concentrations/intensities of ${ }^{238} \mathrm{U}$ and ${ }^{235} \mathrm{U}$ can be represented by straight lines in logarithmic scale, thus the decrease can be described some power dependence of distance covered by the migration. Further experimental details of the measurements are described in [33].

A rough estimation can be performed by using the square-root approximation mentioned with Eg (5). Inserting $4 \mathrm{~mm}$ and 1900 days into Eq (5), a nominal Deff $\approx 10^{-13} \mathrm{~m}^{2} \mathrm{~s}^{-1}$ can be obtained. 
This value is less with two orders of magnitude than those obtained for the mobile iodine and HTO, and is less with one order of magnitude obtained for the less mobile hydrocarbonate and technetate (shown in Table 6). Thus this comparison with neutral and anionic species can also be considered as an indirect proof the measurements with uranium. The slow migration of uranium can probably be attributed to more than one single factor. Beside chemisorption of uranyl ions on clay minerals interaction with (hydro)carbonate anions may take place with forming partly immoblie carbonate species (see the Eh-pH diagram in Figure 12). $\mathrm{Fe}^{2+} / \mathrm{Fe}^{3+}$ ratios were measured by Mössbauer spectroscopy in the surface layers of the borecore samples after having the uranium break-through measurements finished. They were the same as at the start. In consequence the $\mathrm{Fe}^{2+} \rightarrow \mathrm{Fe}^{3+}$ process coupled with $\mathrm{U}(\mathrm{VI}) \rightarrow \mathrm{UO}_{2}$ reduction, as mentioned in the introductory part of this section, does not play role [33].

\section{Summary}

Certain claystones have been considered as appropriate media for long time isolation of high level nuclear waste depositories. Various interactions between the migrating anionic and/or cationic species of radionuclides with the constituents of minerals may take place. For example, the open, layered structure of clay minerals is advantageous for this purpose resulting in high ad- and chemisorption capacities to retard migration of long life-time radioisotopes. Characteristic related properties of different clayrock formations considered as possible hosts in Europe are briefly mentioned and compared. Boda Claystone is discussed in more detail, diagenesis, lithology and mineralogical properties are described. Results of various specific measurements on claystone samples are presented. Particular attention is devoted to sorption and diffusion measurements performed with anionic fission product and actinide radionuclides. From these results some characteristic distances which can be traversed by these radionuclides in the clay rock during the life time of the depository site are estimated.

\section{Author details}

Károly Lázár*

Centre for Energy Research, Institute of Isotopes, Hungarian Academy of Sciences, Budapest, Hungary

Zoltán Máthé

Mecsekérc Plc., Pécs, Hungary

\section{Acknowledgement}

The research leading to these results has received funding from the European Union's European Atomic Energy Community's (EURATOM) sixth and seventh Framework Programmes under grant agreements FP6-516514 (FUNMIG) and FP7-212287 (ReCosy), respectively. The authors are thankful for the fruitful informations and knowledge provided by the opportunity with the participation in these projects. Special thanks are due to the

\footnotetext{
${ }^{*}$ Coresponding Author
} 
colleagues who participated the work in its different stages (J. Megyeri, P. Mell., T. Szarvas, and late L. Riess, at the Institute of Isotopes), and particular thanks are also due to colleagues who contributed to the characterisation of samples by analysing them with specific and unique methods (J.-C. Parneix and M. Perdicakis). The courtesy of PURAM for providing the samples for analysis is also appreciated.

\section{References}

[1] Ojovan M.I, Lee W.E, (2005) An Inroduction to Nuclear Waste Immobilisation, Elsevier, $310 \mathrm{p}$.

[2] Lieser K H (1997) Nuclear and Radiochemistry: Fundamentals and Applications, VCH, Wiley, Weinheim, $460 \mathrm{p}$.

[3] Extrapolation of Short Term Observations to Time Periods Relevant to the Isolation of LongLived Radioactive Waste, IAEA-TECDOC-1177, IAEA, Vienna, (2000) $104 \mathrm{p}$.

[4] Brookins D G, (1988), Eh-pH Diagrams for Geochemistry, Springer, Berlin 176 p.

[5] Brookins D G (1984) Geochemical Aspects of Radioactive Waste Disposal, Springer, Berlin. 347 p.

[6] Stability and Buffering Capacity of the Geosphere for the Long-term Isolation of Radioactive Waste (Application to Argillaceous Media), "Clay Club” Workshop Proceedings, Braunschweig, Germany, Dec. 2003, OECD 2004, NEA 5303, 244 p.

[7] Clay in Natural and Engineered Barriers for Radioactive Waste Confinement, Ed: Aranyossy J-F. Special issue of Physics and Chemistry of the Earth, Vol. 32 (2007) 965 p.

[8] The Use of Scientific and Technical Results from Underground Research Laboratory Investigations for the Geological Disposal of Radioactive Waste, IAEA-TECDOC-1243, IAEA, Vienna (2001) 76 p.

[9] Altmann S. (2009) RTD Component 3, in: Fundamental Processes of Radionuclide Migration, FUNMIG Workshop Proceedings, (Ed. Buckau G et al.) Forschungszentrum Karlsruhe, Wissenschaftliche Berichte FZKA 7461, 45 - 82.

[10] Dossier 2005 Argile, Safety Evaluation of a Geological Repository (2005) ANDRA 782 p

[11] Project Opalinus Clay, Safety Report, NAGRA Technical Report 02-05, (2002) 472 p.

[12] Haas J, Péró Cs, (2004), Mesosoic evolution of the Tisza Mega-unit. International Journal of Earth Sciences 93: 297-313.

[13] Konrád Gy, Sebe K, Halász A, Babinszki E, (2010), Sedimentology of a Permian playa lake: the Boda Claystone Formation, Hungary. Geologos 16: 27-41.

[14] Jámbor Á, (1964), Lower Permian formations of the Mecsek Mountains. Manuscript, Mecsek Ore Environment Company, Pécs (In Hungarian.)

[15] Barabás A, Barabás-Stuhl Á, (1998), Stratigraphy of the Permian formations in the Mecsek Mountains and its surroundings. In: Stratigraphy of Geological Formations of Hungary. Mol Plc. and Hung. Geol. Institute, Budapest, pp. 187-215. (In Hungarian.)

[16] Summary Report of the Site Characterisation Program of the Boda Siltstone Formation (1998), Vol 4. Ed: Máthé Z., Manuscript, Mecsek Ore Environment Co., Pécs. 76 p.

[17] Árkai P, Balogh K, Demény A, Fórizs I, Nagy G, Máthé Z, (2000), Composition, diagenetic and post-diagenetic alterations of a possible radioactive waste repository site: the Boda Albitic Claystone Formation, southern Hungary. Acta Geologica Hungarica, 43: 351-378. 
[18] R-Varga A, Szakmány Gy, Raucsik B, Máthé Z, (2005), Chemical composition, provenance and early diagenetic processes of playa lake deposits from the Boda Siltstone Formation (Upper Permian), SW Hungary. Acta Geol. Hungarica 48: 49-68.

[19] R-Varga A, Raucsik B, Szakmány Gy, Máthé Z, (2006), Mineralogical, petrological and geochemical characteristics of the siliciclastic rock types of Boda Siltstone Formation. Bulletin of the Hungarian Geological Society, 136: 201-232.

[20] Digest on the Results of the Short-term Characterisation of the Boda Claystone Formation, Ed. Kovács L., Mecsekérc-Puram, Pécs-Paks, (1999) 61 p.

[21] Szűcs I., Csicsák J., Óvári Á., Kovács L., Nagy Z. (2004) Confinement performance of Boda Claystone Formation, Hungary, in: Stability and Buffering Capacity of the Geosphere for the Long-term Isolation of Radioactive Waste (Application to Argillaceous Media), „Clay Club" Workshop Proceedings, OECD 2004, NEA 5303. p. 209-224.

[22] Mösssbauer Mineral Handbook (1998) Eds: Stevens J.G. et al., Mössbauer Effect Data Center, $527 \mathrm{p}$.

[23] Lázár K, Máthé Z, Földvári M (2010) Various redox conditions in Boda Claystone as reflected in the change of $\mathrm{Fe}^{2+} / \mathrm{Fe}^{3+}$ ratio in clay minerals, Journal of Physics: Conference series 217: 012053.

[24] Perdicakis M, Xu Y L, Lázár K., Máthé Z., Rouillard L., (2012) Voltammetric characterization of Boda Albitic Claystone: Comparison with Mössbauer spectroscopy data, Electroanalysis, submitted.

[25] Mell P, Megyeri J, Riess L, Máthé Z, Csicsák J, Lázár K (2006) Sorption of Co, Cs, Sr and I onto argillaceous rock as studied by radiotracers, Journal of Radioanalytical and Nuclear Chemistry, 268: 405-410

[26] Sipos P, Németh T, Máthé Z (2010) Preliminary results on the Co, Sr and Cs sorption properties of the analcime-containing rock type of the Boda Siltstone Formation, Central European Geology, 53: 67-78.

[27] Fedor F, Hámos G, Jobbik A, Máthé Z, Somodi G, Szűcs I (2008) Laboratory pressure pulse decay permeability measurement of Boda Claystone, Mecsek Mts., SW Hungary, Physics and Chemistry of the Earth 33: S45-S53.

[28] Lázár K, Megyeri J, Parneix J-C, Máthé Z, Szarvas T, (2009) Diffusion of anionic species (99TcO4-, H14CO3-) and HTO in Boda Claystone borecore samples, in: Fundamental Processes of Radionuclide Migration, FUNMIG Workshop Proceedings, (Ed. Buckau G et al.) Forschungszentrum Karlsruhe, Wissenschaftliche Berichte FZKA 7461, 199 - 204.

[29] Mell P, Megyeri J, Riess L, Máthé Z, Hámos G, Lázár K (2006) Diffusion of Sr, Cs, Co and I in argillaceous rock as studied by radiotracers, Journal of Radioanalytical and Nuclear Chemistry, 268: 411-417

[30] Rose D A, (1963) Water movement in porous materials, British Journal of Applied Physics, 14: 256-262

[31] Erdey Grúz T., Schay G, (1962) Theoretical Physical Chemistry, Tankönyvkiadó, Budapest, Vol 3. 447 p. (in Hungarian)

[32] Altmann S, Tournassat C, Goutelard F, Parneix J-C, Gimmi T, Maes N, (2012) Diffusiondriven transport in clayrock formations, 27: 463-478.

[33] Lázár K, Megyeri J, Mácsik Zs, Széles É, Máthé Z, (2011) Migration of uranyl ions in Boda Claystone samples, in: Redox Phenomena Controlling Systems, RECOSY 3rd Annual Workshop Proceedings, (Ed. Altmaier M, et al.) KIT Scientific Reports 7603, 91-97 